\title{
Alteration of babassu biodiesel properties through camphor and biodiesel of tung
}

\section{Alteração das propriedades do biodiesel de babaçu por meio de cânfora e biodiesel de tungue}

\author{
Camila Cassia Cordeiro ${ }^{1}$; Julio Cezar Girardi ${ }^{2}$; Reinaldo Aparecido Bariccatti ${ }^{3}$; \\ Douglas Cardoso Dragunski ${ }^{4}$; Camila Zeni do $\mathrm{Amaral}^{5}$
}

\begin{abstract}
Babassu oil is extracted from the babassu palm, one of the most important plants in the north and northeast Brazilian regions, and like many biofuels, it does not have adequate properties to be used as pure fuel, especially under low-temperature conditions. Therefore, researches to improve the physical-chemical properties of these biofuels are needed, one of the most common methods is using additives, usually synthetic ones, which are not environmentally friendly. A good alternative would be to try to found natural compounds with this potential. This paper describes the effects of the addition of two natural compounds, tung biodiesel, and camphor, in the physical properties of babassu biodiesel. These additives were select because of their physical-chemical properties, which can potentially improve the babassu biodiesel ones. They were tested separately, the camphor at the 3,4,5,6\% proportions, and the tung biodiesel at 3,5, 9, $12 \%$. The results were compared to biodiesel standards, limited by the Brazilian National Agency of Petroleum, Natural Gas, and Biofuels (ANP), and for both additives, the $3 \%$ proportion showed the best suited to the quality standards established at the Brazilian normative. Thus, was observed that the camphor and the tung biodiesel has the potential to be efficient additives in babassu biodiesel.
\end{abstract}

Keywords: Blends. Biofuel. Natural additives. Freezing point. Viscosity.

\section{Resumo}

O óleo de babaçu é extraído da palmeira de babaçu, uma das plantas mais importantes das regiões Norte e Nordeste do Brasil, e como muitos biodieseis, o biodiesel de babaçu não possui propriedades adequadas para ser utilizado como combustível puro. Portanto, pesquisas para melhorar as propriedades físico-químicas desses biocombustíveis são necessárias, um dos métodos mais comuns é a utilização de aditivos, geralmente sintéticos, que não são ecologicamente corretos. Uma boa alternativa seria tentar encontrar compostos naturais que se enquadrem como aditivos para o biodiesel. Este artigo descreve os efeitos da adição de dois compostos naturais, biodiesel de tungue e cânfora, nas propriedades físicas do biodiesel de babaçu. Estes compostos foram testados separadamente a canfora nas proporções de $3,4,5,6 \%$ e o biodiesel de tungue em 3,5 , 9, $12 \%$. Os resultados foram comparados aos padrões de biodiesel, limitados pela Agência Nacional do Petróleo, Gás Natural e Biocombustíveis (ANP), e para ambos os aditivos, a proporção de $3 \%$ mostrou-se mais adequada a normativa brasileira. Observou-se que a cânfora e o biodiesel de tungue têm potencial para serem aditivos eficientes no biodiesel de babaçu.

Palavras-chave: Blendas. Biocombustível. Aditivos naturais. Ponto de congelamento. Viscosidade.

\footnotetext{
${ }^{1}$ Mestranda, Prog. de Pós-Grad. em Eng. Química, UNIOESTE, Toledo, Paraná, Brasil, E-mail: camilacassiacordeiro@ hotmail.com

2 Doutorando, PPGEA, UNIOESTE, Cascavel, Paraná, Brasil E-mail: juliocgirardi@gmail.com

${ }^{3}$ Prof. Dr., Dptos. Química e Eng. de Energia na Agricultura, UNIOESTE, Toledo, Paraná, Brasil E-mail: bariccatti@ yahoo.com.br

${ }^{4}$ Prof. Dr., Dpto. de Química, UNIOESTE, Toledo, Paraná, Brasil, E-mail: dcdragunski@ gmail.com

${ }^{5}$ Mestranda do Curso de Eng. de Energia na Agricultura, UNIOESTE, Cascavel, PR, Brasil, E-mail: camilazamaral@gmail.com
} 


\section{Introduction}

Automobile fuels are great emitters of greenhouse gases and, therefore, it is important to produce more environmentally-friendly biofuels and to improve the physical-chemical properties of these fuels to make them more efficient biofuels (ATMANLI, 2016; GONCA; DOBRUCALI, 2016; RUHUL et al., 2016; KUMAR; SUBRAMANIAN, 2017; MAGRO et al., 2016).

Biodiesel is a renewable, biodegradable and, nontoxic fuel that can be obtained by transesterification reactions of vegetable oils. However, it has physicalchemical properties that, if not improved, can damage the engines, like viscosity, density and, freezing point. Thus, researches have been conducting to improve these properties, such as mixing additives (ABE et al., 2016; CAMPOS FILHO et al., 2015; ROMAGNOLI et al., 2018; SENRA; MCCARTNEY; SOH, 2019; SECCO et al., 2017; VARATHARAJAN; PUSHPARANI, 2018; VALENGA et al., 2019).

Among the biodiesel physicochemical properties, the freezing point is one that should be improved. Because of the freeze-crystallization, the biofuel can become so compact as to obstruct the fuel supply lines in the engine. Thus, the purpose of this study, and several others, is to perform biodiesel freeze at a much lower temperature, especially in the cold climate region (MONIRUL et al., 2017; SENRA; MCCARTNEY; SOH, 2019; KNOTHE; RAZON, 2017; XUE et al., 2016).

One way to improve these properties without production expenses is by adding substances that change the biodiesel molecular dynamic. The additives are used for many purposes, to prevent deterioration like BHA, BHT, and TBHQ, improve physical properties and improve the freezing points as derived from petroleum products, but usually, these additives are synthetic ones (BORSATO $e t$ al., 2014; MAIA et al., 2011; RIZWANUL FATTAH et $a l ., 2014)$. A more sustainable alternative is to search for additives from natural sources because they provide benefits, as being renewable, non-toxic, and usually cheaper than the synthetic ones (BHARTI; SINGH, 2020; BUOSI et al., 2016).

The babassu palm (Orbignya phalerata, Mart.) is one of the most important palm trees in the north and northeast Brazilian regions because the commercial purpose of wood and straw handicrafts of this plant (OLIVEIRA et al., 2013). The babassu biodiesel has low molecular weight and few double bonds with predominantly of lauric acid (C12: 0), causing it to have low viscosity and inferior freezing properties (SANTOS et al., 2007; SILVA et al., 2010).

Our study's purpose was to used natural additives as camphor and tung biodiesel to control the babassu biodiesel physical-chemical properties. Camphor is a chemical compound that can be extracted from the camphor plant (Cinnamomum camphora), and tung biodiesel is a fatty acid ester obtained from tung oil transesterification.

Both camphor and tung biodiesel were select to be tested as additives in babassu biodiesel because they chemical structure, cost, and as they have physicalchemical characteristics that can be complements to babassu biodiesel, as good freezing properties and high molecular mass.

Tung biodiesel has predominant alpha Eleostearic acid (C18:3), has CFPP of $-11{ }^{\circ} \mathrm{C}$ and $9.8 \mathrm{~mm} / \mathrm{s}^{2}$ viscosity at $40{ }^{\circ} \mathrm{C}$ (PARK et al., 2008) these are the main characteristics that lead to test this biodiesel as an additive, was expected that the babassu low viscosity improves the blend viscosity and the tung biodiesel reduce the babassu biodiesel pour point.

Camphor was a tridimensional chemical structure, expected its structure creates difficulties in the biodiesel crystallization process. The main chemical structure of the additives is in Figure 1.

\section{Material and methods}

\section{Material}

We obtained the babassu oil and the tung oil through Campestre, 2020 company. The camphor and the sodium methoxide $\left(\mathrm{CH}_{3} \mathrm{NaO}\right.$, p.a.) were obtained through the chemistry research group at the Western Paraná State University (UNIOESTE). And all the equipment that we used in this study were provided by the same university.

\section{Production of babassu and tung biodiesel, and the blends babassu/tung and babassu/camphor}

The biodiesels were synthesized by methylic route and homogeneous catalyst, using the sodium methoxide $\left(\mathrm{CH}_{3} \mathrm{ONa}\right.$, p.a.). The alcohol: oil volume ratio was 1:3 (v/v) and the catalyst concentration of $1 \%$ (v). The system was kept at $60{ }^{\circ} \mathrm{C}$ and mechanically stirred for 1 hour. Then, it was transferred to a separator funnel, to separate the glycerin. The purification was performed by three successive washes with distilled water and drying for $1 \mathrm{~h}$ at $60{ }^{\circ} \mathrm{C}$. 
Figure 1 - Chemical structure of the additives.

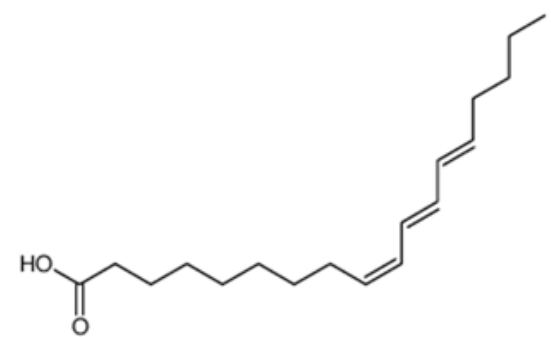

(a) alpha- Eleostearic acid

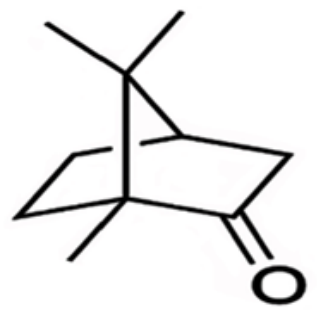

(b) Camphor

Source: The authors.

After we produce the biodiesels, we did the blends procedure. To the blends between babassu biodiesel and tung biodiesel were used the proportions of 3, 5, 9, and $12 \%(\mathrm{v} / \mathrm{v})$. To the blends between camphor and babassu biodiesel, we described in Table 1.

Table 1 - Quantity of camphor added to babassu biodiesel.

\begin{tabular}{cc}
\hline $\begin{array}{c}\text { Percentage of camphor in } \\
\text { babassu biodiesel (\%) }\end{array}$ & $\begin{array}{c}\text { Camphor added to get } \\
\text { the percentage (g) }\end{array}$ \\
\hline Babassu 97\% - Camphor 3\% & 0.75 \\
Babassu 96\% - Camphor 4\% & 1.00 \\
Babassu 95\% - Camphor 5\% & 1.25 \\
Babassu 94\% - Camphor 6\% & 1.50 \\
\hline
\end{tabular}

Source: The authors.

All procedures, Table 1, were described briefly in Figure 2.

\section{Biodiesels and blends density}

The relative density of each sample was determined by the pycnometer method (ASTM D 4052 standard). The pycnometer is a small glass bottle constructed in a way that the volume of liquid that is contained therein is invariable. The procedure has used a 12-ml pycnometer, a precision balance, and distilled water for comparison purposes. The process consists of measuring the mass of water and fluid that fills the pycnometer. The ratio between the mass of the fluid and the mass of water is the relative density.

\section{Biodiesels and blends viscosity}

To performer the kinematic viscosity analysis, we used the ASTM D 445 standard. It consists of using a capillary viscometer, with flow under gravity, set over a heating bath.
We use a Cannon Fenske 75 capillary viscometer. The flow time was writing down and the calculation was made by multiplying the flow time in seconds by the viscometer constant, using a $0.008 \mathrm{~mm}^{2} / \mathrm{s}$ for the Cannon Fenske $75 \mathrm{~mL}$. We performed this procedure at the temperatures $25^{\circ} \mathrm{C}, 30^{\circ} \mathrm{C}, 35^{\circ} \mathrm{C}$ and $40{ }^{\circ} \mathrm{C}$.

\section{Biodiesels and blends pour point (PP)}

Pour point test was performed by the ASTM D97. To this procedure, some modifications were made to obtain a more precise result. Instead of using mercury thermometric, we use a platinum sensor pt-100 term thermometer, with precision measurement of $0.01{ }^{\circ} \mathrm{C}$, and to the lowtemperature thermostatic refrigerated bath, the temperature was set up as $-15^{\circ} \mathrm{C}$ to $5^{\circ} \mathrm{C}$.

Infrared spectrum of tung and babassu oils and biodiesel

The infrared absorption spectra were performed on a Frontier spectrometer, ranging from $4000-400 \mathrm{~cm}^{-1}$, on an ATR accessory.

\section{Statistical analysis}

Only basic statistical analysis was used, such as means and standard deviation. All statistical analyzes were performed in the program Microsoft Excel 2016.

\section{Results and discussion}

\section{Blends babassu-tung density}

The tung biodiesel has a magnifying effect on the babassu biodiesel density, once the samples with higher tung biodiesel proportions, such as $9 \%$ and $12 \%$, have higher densities. This variation can be explained because tung biodiesel has a higher specific weight 
Figure 2 - Route for babassu biodiesel production and blends with the additives.

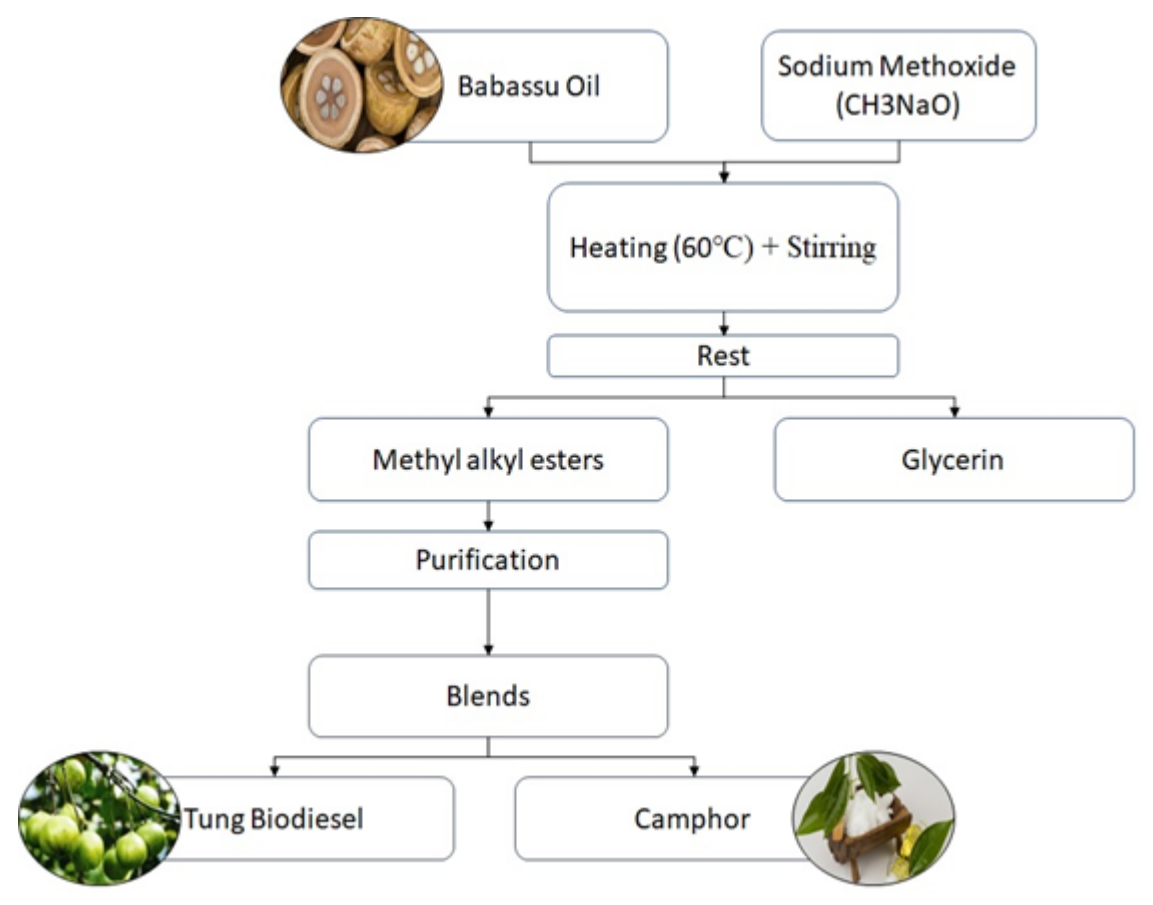

Source: The authors.

(0.934 - $\left.0.943 \mathrm{gcm}^{-3}\right)$ than babassu biodiesel (0.903 $0.924 \mathrm{gcm}^{-3}$ ), and a longer carbon chain (CAMPESTRE, 2020). In Table 2 , this effect can be observed.

Although blends had increased the density, none sample was over specification determined by the Brazilian National Petroleum Agency (ANP) standard from 0.85 to 0.90 g.mL, except for the tung biodiesel (ANP, 2014).

\section{Blends babassu-tung viscosity}

There was a variation in viscosity according to the different compositions of the mixtures. Tung biodiesel composition caused an increase in the viscosity of the samples in all temperatures tested. The viscosity variation between these biodiesels is shown in Table 3.

This effect can be explained by the fact that tung biodiesel has a larger carbon chain, causing a greater number of intermolecular interactions between the two biodiesels, and these interactions become hinder the flow of biodiesel, increasing the viscosity.

The Brazilian National Petroleum Agency (ANP) viscosity standard at $40{ }^{\circ} \mathrm{C}$ is 3.0 to $6.0 \mathrm{cSt}$, so, although the viscosity-increasing, all mixtures meet the standard.

\section{Blends babassu-tung pour point (PP)}

In Table 4 is observed the pour point temperatures for biodiesel blends.

According to the data obtained, small amounts of tung biodiesel ( $3 \%$ ) improves the pour temperature and higher concentrations tend to worsen the pour point. Thus, the $3 \%$ blend showed the best result with a temperature of $-8.5^{\circ} \mathrm{C}$, improving the pour point of babassu biodiesel.

The study developed by (YUAN et al., 2017) demonstrates the dependence of the cold filter plugging point on the profile of saturated fatty acids present in biodiesel blends.

In case of biodiesel blends which have short saturated fatty acid chains, like babassu biodiesel (C12:0, C14:0), with longer unsaturated fatty acid chains, like tung biodiesel (C18:3), was observed a slight improvement in the cold filter plugging point, until $20 \%$ of long-chain unsaturated fatty acid biodiesel.

For the blend between babassu biodiesel and tung biodiesel, our study shows that this optimal blend percentage to the pour point is lower, around $3 \%$ of the long-chain unsaturated fatty acid biodiesel. 
Table 2 - Density of babassu biodiesel blends with tung biodiesel.

\begin{tabular}{ccc}
\hline $\begin{array}{c}\text { Blends babassu- } \\
\text { tung percentage }\end{array}$ & $\begin{array}{c}\text { Blends } \\
\text { weight }(\mathbf{g})\end{array}$ & $\begin{array}{c}\text { Blends density }) \\
(\text { g.mL }\end{array}$ \\
\hline Babassu 97\% - Tung 3\% & 22.1584 & 0.8732 \\
Babassu 95\% - Tung 5\% & 22.1908 & 0.8745 \\
Babassu 91\% - Tung 9\% & 22.2486 & 0.8768 \\
Babassu 88\% - Tung 12\% & 22.2489 & 0.8769 \\
Pure Tung biodiesel & 23.0965 & 0.9102 \\
\hline
\end{tabular}

Source: The authors.

Table 3 - Viscosity (Cst) and standard deviation for babassu biodiesel blends with tung biodiesel.

\begin{tabular}{ccccc}
\hline & \multicolumn{4}{c}{$T$} \\
\cline { 2 - 5 } & $25^{\circ} \mathbf{C}$ & $30{ }^{\circ} \mathbf{C}$ & $35^{\circ} \mathbf{C}$ & $40{ }^{\circ} \mathbf{C}$ \\
\hline Pure pabassu biodiesel & $4.72 \pm 0.21$ & $4.24 \pm 0.07$ & $3.74 \pm 0.02$ & $3.36 \pm 0.02$ \\
Babassu 97\% - Tung 3\% & $4.85 \pm 0.32$ & $4.25 \pm 0.01$ & $3.88 \pm 0.03$ & $3.48 \pm 0.01$ \\
Babassu 95\% - Tung 5\% & $4.89 \pm 0.06$ & $4.34 \pm 0.10$ & $3.90 \pm 0.02$ & $3.48 \pm 0.01$ \\
Babassu 91\% - Tung 9\% & $5.27 \pm 0.02$ & $4.64 \pm 0.01$ & $4.14 \pm 0.01$ & $3.71 \pm 0.01$ \\
Babassu 88\% - Tung 12\% & $5.53 \pm 0.01$ & $4.96 \pm 0.01$ & $4.34 \pm 0.01$ & $3.90 \pm 0.01$ \\
\hline
\end{tabular}

Source: The authors.

Table 4 - Freeze test temperatures for babassu biodiesel blends with tung biodiesel.

\begin{tabular}{cc}
\hline Blends & T $\left({ }^{\circ} \mathbf{C}\right)$ \\
\hline Pure Babassu Biodiesel & -7.87 \\
Babassu 97\% - Tung 3\% & -8.50 \\
Babassu 95\% - Tung 5\% & -6.90 \\
Babassu 91\% - Tung 9\% & -6.50 \\
Babassu 88\% - Tung 12\% & -5.00 \\
Pure Tung Biodiesel & 0.00 \\
\hline
\end{tabular}

Source: The authors.

\section{Infrared spectrum of tung and babassu oils and biodiesel}

For comparison purposes, besides analyzing the infrared spectrum of babassu and tung biodiesel, also the soybean biodiesel was analyzed, as the respective oils used as raw materials to biodiesels production.

The spectra are in Figure 3, can be observed that transesterification occurred, since the band associated with asymmetric vibration of O-C-C does not exist in biodiesel, consequently, the band close to $1100 \mathrm{~cm}^{-1}$ has an intensity reduce, as well as the asymmetric deformation at $1450 \mathrm{~cm}^{-1}$ of $\mathrm{CH}_{3}$ is accentuated in biodiesel. Another evidence in this spectrum is the absence of water and alcohol, as its band in the region of
$3500 \mathrm{~cm}^{-1}$ does not appear (MAZIVILA et al., 2015; MUMTAZ et al., 2012).

The infrared spectrum was performed to confirm the transesterification of the biodiesels. It is possible to observe that for soybean and tung biodiesel, the bands close to $1100 \mathrm{~cm}^{-1}$ does not exist anymore in relation to their respective oil's spectrum, whereas, in babassu biodiesel, the band close to this wave number decreases markedly when compared to the oil of its raw material. Furthermore, the infrared spectrum can indicate the purity in the biodiesel compositions through the absence of the water and alcohol band in $3500 \mathrm{~cm}^{-1}$.

About the composition, both soybean and tung biodiesels show double bonds in their carbon chain, once both biodiesels have a band appears around $3100 \mathrm{~cm}^{-1}$. Nevertheless, this band does not appear in the babassu biodiesel spectra, thus indicated that this biodiesel has few unsaturations in its composition.

\section{Blends babassu-camphor density and viscosity}

The principal fuel dynamic properties are viscosity and density because of their directly influences the fuel circulation and injection. Therefore, any modifications in these properties should be carefully controlled (GÜLÜM; BILGIN, 2015; KANAVELI; ATZEMI; LOIS, 2017). 
Figure 3 - The infrared spectrum of tung, soybean and babassu biodiesel, and their oils.

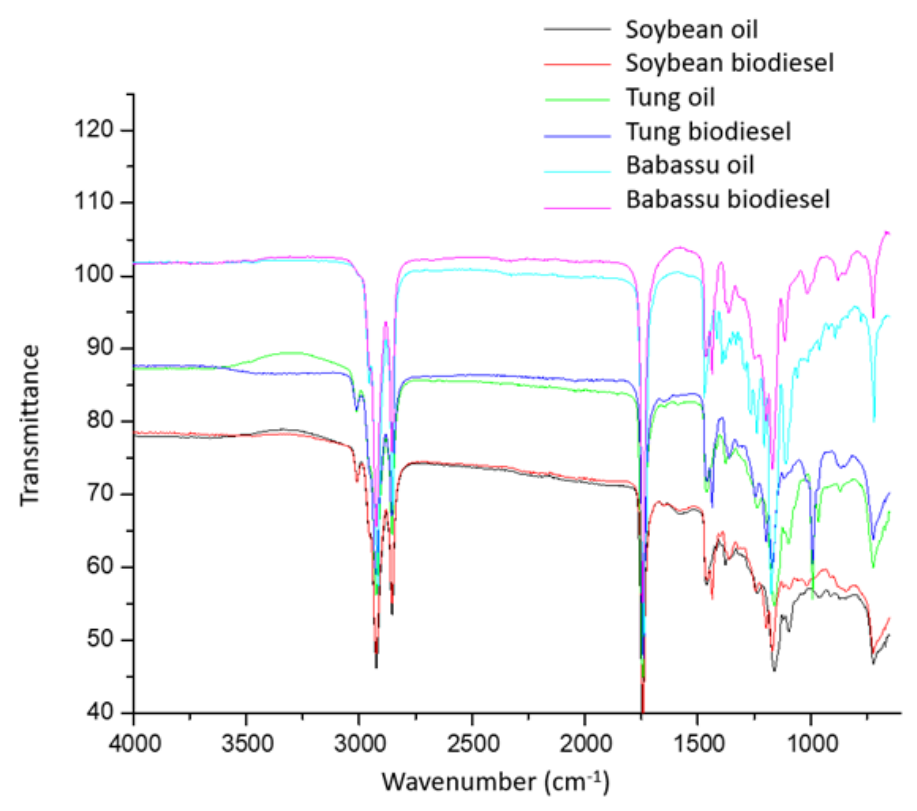

Source: The authors.

Table 5 shows the effects of camphor addition in the babassu biodiesel density and Table 6 shows the effects of blends in babassu biodiesel viscosity.

The addition of camphor decreases the biodiesel density considerably and all the samples meet the standard set by ANP. A promising result, whereas, which a high biodiesel density, the engine functioning is affected.

Only $3 \%$ camphor in babassu biodiesel showed a marked reduction in viscosity compared to babassu biodiesel $(0 \%)$. Thus, a likely cause is that given the structure of camphor, it induces a breakdown and separation between the carbon chains of biodiesel, reducing its viscosity.

Nevertheless, the higher percentages didn't present a greater reduction, it can be linked to the effect in the density who also decreases at $3 \%$ and doesn't present a greater decrease in the higher percentages.

Figure 4 presents the graph with the relation temperature and viscosity for the camphor/biodiesel blends.

Viscosity and density are indicatives of the increase/decrease of intermolecular interactions. When viscosity increases became difficult for biofuels to pass through the engines. Therefore, as there was no increase in viscosity results, camphor indicated a potential additive for babassu biodiesel. Also, all the samples were in agreement with the technical regulation established by ANP.

\section{Blends babassu-camphor pour point (PP)}

The pour point analysis is observed in Table 7 and shows that the $6 \%$ camphor proportion presented the lowest pour point temperature. Nevertheless, there was a small variation between $3 \%$ and $6 \%$ results, which demonstrates that the $3 \%$ solution is more efficient and, consequently, most advantageous.

Researches show that additives affect the physicalchemical properties like freezing points, oxidative stability, heating values, among others. Although some additives improve freezing properties, this addition tends to reduced others, such as density and viscosity (ALI; MAMAT; FAIZAL, 2013).

Usually, researches with antifreeze additives use synthetic additives like alternatives to improve the freezing properties of biodiesels, such as the poly-alpha olefin and methyl polyacrylate (MONIRUL et al., 2017; XUE et al., 2016). A more environmentally friendly alternative would be the use of natural additives, such as camphor, extracted from the Cinnamomum camphora plant.

Monirul et al. (2017) used the methyl polyacrylate additive in blends with coconut biodiesel and diesel, and it obtained an improvement of the cloud point at $3{ }^{\circ} \mathrm{C}$. Xue et al. (2016) used the poly-alpha-olefin blend in biodiesel from reused cooking oil (which has many unsaturations in its carbon chain), obtained an improvement of the biodiesel cloud point in $5^{\circ} \mathrm{C}$. 
Table 5 - Measurement of density of babassu biodiesel blends with camphor.

\begin{tabular}{ccc}
\hline $\begin{array}{c}\text { Blends } \\
(\%)\end{array}$ & $\begin{array}{c}\text { Camphor added to babassu } \\
\text { biodiesel (g) }\end{array}$ & $\begin{array}{c}\text { Density } \\
(\text { g.mL-1) }\end{array}$ \\
\hline Pure Babassu Biodiesel & 0.00 & 0.8889 \\
Babassu 97\% - Camphor 3\% & 0.75 & 0.8821 \\
Babassu 96\% - Camphor 4\% & 1.00 & 0.8825 \\
Babassu 95\% - Camphor 5\% & 1.25 & 0.8834 \\
Babassu 94\% - Camphor 6\% & 1.50 & 0.8847 \\
\hline
\end{tabular}

Source: The authors.

Table 6 - Viscosity (Cst) and standard deviation for babassu biodiesel blend with camphor.

\begin{tabular}{ccccc}
\hline & \multicolumn{4}{c}{$T$} \\
\cline { 2 - 5 } & $25^{\circ} \mathbf{C}$ & $30^{\circ} \mathbf{C}$ & $35^{\circ} \mathbf{C}$ & $40{ }^{\circ} \mathbf{C}$ \\
\hline Pure Babassu Biodiesel & $4.72 \pm 0.21$ & $4.24 \pm 0.07$ & $3.74 \pm 0.02$ & $3.36 \pm 0.02$ \\
Babassu 97\% - Camphor 3\% & $4.34 \pm 0.057$ & $3.85 \pm 0.011$ & $3.44 \pm 0.017$ & $3.10 \pm 0.034$ \\
Babassu 96\% - Camphor 4\% & $4.38 \pm 0.045$ & $3.89 \pm 0.034$ & $3.52 \pm 0.045$ & $3.13 \pm 0.017$ \\
Babassu 95\% - Camphor 5\% & $4.34 \pm 0.034$ & $3.89 \pm 0.017$ & $3.47 \pm 0.011$ & $3.16 \pm 0.051$ \\
Babassu 94\% - Camphor 6\% & $4.46 \pm 0.068$ & $3.93 \pm 0.011$ & $3.57 \pm 0.040$ & $3.18 \pm 0.011$ \\
\hline
\end{tabular}

Source: The authors.

Figure 4 - Graph with viscosity relative to camphor composition added to babassu biodiesel.

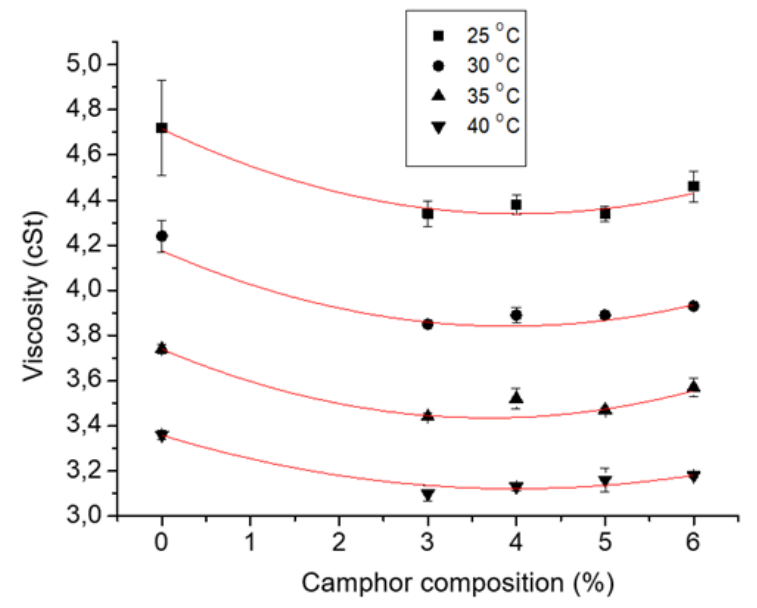

Source: The authors.

Camphor, although a natural compound, reduced the babassu biodiesel freezing point at $2{ }^{\circ} \mathrm{C}$, a similar result to the Monirul et al. (2017) research, with coconut biodiesel and methyl polyacrylate as additive. Considering that both biodiesels have similar structural characteristics, the camphor show results to improve biodiesel freezing point similar to synthetic additives.
As described, the camphor had a reductive effect on all the physicochemical properties tested to babassu biodiesel. However, it was possible to observe a trend of increase in density and viscosity from the $3 \%$ proportion. 
Table 7 - Temperatures of the freezing test of the babassu biodiesel blends with camphor.

\begin{tabular}{cc}
\hline Blends & $T\left({ }^{\circ} \mathbf{C}\right)$ \\
\hline Pure Babassu Biodiesel & -7.87 \\
Babassu 97\% - Camphor 3\% & -9.05 \\
Babassu 96\% - Camphor 4\% & -9.30 \\
Babassu 95\% - Camphor 5\% & -9.92 \\
Babassu 94\% - Camphor 6\% & -10.20 \\
\hline
\end{tabular}

Source: The authors.

\section{Conclusion}

All the physical-chemical results obtained by the addition of tung biodiesel and camphor are within the biodiesel quality norm established by the Brazilian National Petroleum Agency (ANP) standard.

The $3 \%$ tung biodiesel proportion had the best results in all the evaluated properties using this additive, with a density of $0.8732 \mathrm{~g} . \mathrm{mL}^{-1}$, viscosity at $40{ }^{\circ} \mathrm{C}$ of $3.48 \mathrm{Cst}$, and pour point of $-8.50{ }^{\circ} \mathrm{C}$. Proportion of tung biodiesel greater than $3 \%$ worsened the babassu biodiesel properties.

To camphor, the best pour point improvement was at the $6 \%$ proportion, $-10.20{ }^{\circ} \mathrm{C}$. However, the $3 \%$ proportion had the best results for viscosity at $40{ }^{\circ} \mathrm{C}, 3.10$ Cst, and density, 0.8821 g.mL ${ }^{-1}$, and a good pour point improvement too, $-9.05^{\circ} \mathrm{C}$.

Camphor was considered a better additive than tung biodiesel, as it improves all the physicochemical properties tested for all the mixtures.

\section{Acknowledgments}

The authors are grateful for the financial support provided by the Brazilian agency CAPES through the master's degree grant.

\section{References}

ABE, M.; HIRATA, S.; KOMATSU, H.; YAMAGIWA, K.; TAJIMA, H. Thermodynamic selection of effective additives to improve the cloud point of biodiesel fuels. Fuel, London, v. 171, p. 94-100, 2016.

ANP - AGÊNCIA NACIONAL DO PETRÓLEO GÁS NATURAL E BIOCOMBUSTÍVEIS. Resolução ANP $n^{o}$ 45, de 25.8.2014. Rio de Janeiro: ANP, 2014. Available from: <http://legislacao.anp.gov.br/?path=legisl acao-anp/resol-anp/2014/agosto\&item=ranp-45-2014> . Acess in: July 20, 2020.
ALI, O. M.; MAMAT, R.; FAIZAL, C. K. M. Review of the effects of additives on biodiesel properties, performance, and emission features. Journal of Renewable and Sustainable Energy, Oxford, v. 5, n. 1, 2013.

ATMANLI, A. Comparative analyses of diesel-waste oil biodiesel and propanol, n-butanol or 1-pentanol blends in a diesel engine. Fuel, London, v. 176, p. 209-215, 2016.

BHARTI, R.; SINGH, B. Green tea (Camellia assamica) extract as an antioxidant additive to enhance the oxidation stability of biodiesel synthesized from waste cooking oil. Fuel, London, v. 262, p. 116658, 2020.

BORSATO, D.; CINI, J. R. D. M.; SILVA, H. C.; COPPO, R. L.; ANGILELLI, K. G.; MOREIRA, I.; MAIA, E. C. R. Oxidation kinetics of biodiesel from soybean mixed with synthetic antioxidants BHA, BHT and TBHQ: determination of activation energy. Fuel Processing Technology, London, v. 127, p. 111-116, 2014.

BUOSI, G. M.; SILVA, E. T. DA; SPACINO, K.; SILVA, L. R. C.; FERREIRA, B. A. D.; BORSATO, D. Oxidative stability of biodiesel from soybean oil: comparison between synthetic and natural antioxidants. Fuel, London, v. 181, p. 759-764, 2016.

CAMPESTRE. Óleo de Tungue: ficha técnica. São Bernardo do Campo: Campestre, 2020.

CAMPOS FILHO, V. M. ; SPACINO, K. R.; ROMAGNOLI, É. S.; SILVA, L. R. C.; BORSATO, D. Perfil do biodiesel B100 comercializado na região de Londrina: aplicação de redes neurais do tipo mapa auto-organizável. Semina: Ciências Exatas e Tecnológicas, Londrina, v. 36, n. 2, p. $63,2015$.

GONCA, G.; DOBRUCALI, E. Theoretical and experimental study on the performance of a diesel engine fueled with diesel-biodiesel blends. Renewable Energy, Oxford, v. 93, p. 658-666, 2016.

GÜLÜM, M; BILGIN, A. Density, flash point and heating value variations of corn oil biodiesel-diesel fuel blends. Fuel, London, v. 134, p. 456-464, 2015.

KANAVELI, I. P.; ATZEMI, M.; LOIS, E. Predicting the viscosity of diesel/biodiesel blends. Fuel, London, v. 199, p. 248-263, 2017. 
KNOTHE, G; RAZON, L. F. Biodiesel fuels progress in energy and combustion science. Progress in Energy and Combustion Science, Oxford, v. 58, p. 36-59, 2017.

KUMAR, A.; SUBRAMANIAN, K. A. Control of greenhouse gas emissions (CO2, CH4 and N2O) of a biodiesel (B100) fueled automotive diesel engine using increased compression ratio. Applied Thermal Engineering, Oxford v. 127, p. 95-105, 2017.

MAGRO, F. G.; DECESARO, A.; BERTICELLI, R.; COLLA, L. M. Produção de bioetanol utilizando microalgas: uma revisão. Semina: Ciências Exatas e Tecnológicas, Londrina, v. 37, n. 1, p. 159, 2016.

MAIA, E. C. R.; BORSATO, D.; MOREIRA, I.; SPACINO, K. R.; RODRIGUES, P. R. P.; GALLINA, A. L. Study of the biodiesel B100 oxidative stability in mixture with antioxidants. Fuel, London, v. 92, n. 9, p. 1750-1755, 2011.

MAZIVILA, S.; SANTANA, F. B.; MITSUTAKE, H.; GONTIJO, L. C.; SANTOS, D. Q.; BORGES NETO, W. Discrimination of the type of biodiesel/diesel blend (B5) using mid-infrared spectroscopy and PLS-DA. Fuel, London, v. 142, p. 222-226, 2015.

MONIRUL, I. M.; KALAM, M. A.; MASJUKI, H. H.; ZULKIFLI, N. W. M.; SHAHIR, S. A.; MOSAROF, M. H.; RUHUL, A. M. Influence of poly(methyl acrylate) additive on cold flow properties of coconut biodiesel blends and exhaust gas emissions. Renewable Energy, Oxford, v. 101, p. 702-712, 2017.

MUMTAZ, M. W.; ADNAN, A.; ANWAR, F.; MUKHTAR, H.; RAZA, M. A.; AHMAD, F.; RASHID, U. Response surface methodology: an emphatic tool for optimized biodiesel production using rice bran and sunflower oils. Energies, Basel, v. 5, n. 9, p. 3307-3328, 2012.

OLIVEIRA, L. E.; GIORDANI, D. S.; PAIVA, E. M.; CASTRO, H. F. DE; SILVA, M. L. C. P. Kinetic and thermodynamic parameters of volatilization of biodiesel from babassu, palm oil and mineral diesel by thermogravimetric analysis (TG). Journal of Thermal Analysis and Calorimetry, Dordrecht, v. 111, n. 1, p. 155-160, 2013.

PARK, J. Y.; KIM, D. K.; WANG, Z. M.; LU, P.; PARK, S. C.; LEE, J. S. Production and characterization of biodiesel from tung oil. Applied Biochemistry and Biotechnology, Clifton, v. 148, n. 1/3, p. 109-117, 2008.
RIZWANUL FATTAH, I. M.; MASJUKI, H. H.; KALAM, M. A.; MOFIJUR, M.; ABEDIN, M. J. Effect of antioxidant on the performance and emission characteristics of a diesel engine fueled with palm biodiesel blends. Energy Conversion and Management, Amsterdam, v. 79, p. 265-272, 2014.

ROMAGNOLI, É. S.; BORSATO, D.; SILVA, L. R. C.; CHENDYNSKI, L. T.; ANGILELLI, K. G.; CANESIN, E.

A. Kinetic parameters of the oxidation reaction of commercial biodiesel with natural antioxidant additives. Industrial Crops and Products, Amsterdam, v. 125, p. 59-64, 2018.

RUHUL, M. A.; ABEDIN, M. J.; RAHMAN, S. M. A.; MASJUKI, B. H. H.; ALABDULKAREM, A.; KALAM, M. A.; SHANCITA, I. Impact of fatty acid composition and physicochemical properties of Jatropha and Alexandrian laurel biodiesel blends: an analysis of performance and emission characteristics. Journal of Cleaner Production, Oxford, v. 133, p. 1181-1189, 2016.

SANTOS, N. A.; TAVARES, M. L. A.; ROSENHAIM, R.; SILVA, F. C.; FERNANDES, V. J.; SANTOS, I. M. G.; SOUZA, A. G. Thermogravimetric and calorimetric evaluation of babassu biodiesel obtained by the methanol route. Journal of Thermal Analysis and Calorimetry, Dordrecht, v. 87, n. 3, p. 649-652, 2007.

SECCO, W.; SILVA, C. DA; AWADALLAK, J.; SILVA, E. A. DA. Transesterificação do Óleo de Frango Empregando Diferentes Catalisadores. Semina: Ciências Exatas e Tecnológicas, Londrina, v. 38, n. 1, p. 3, 2017.

SENRA, M.; MCCARTNEY, S. N.; SOH, L. The effect of bio-derived additives on fatty acid methyl esters for improved biodiesel cold flow properties. Fuel, London, v. 242, p. 719-727, 2019.

SILVA, F. C.; CAVALCANTE, K. S. B.; LOUZEIRO, H. C.; MOURA, K. R. M., MACIEL, A. P.; SOLEDADE, L. E. B.; SOUZA, A. G. Production of biodiesel from babassu oil using methanol-ethanol blends. Ecletica Química, São Paulo, v. 35, n. 1, p. 47-54, 2010. DOI: https://doi.org/10.1590/S010046702010000100006.

VALENGA, M. G. P.; BOSCHEN, N. L.; RODRIGUES, P. R. P.; MAIA, G. A. R. Agro-industrial waste and Moringa oleifera leaves as antioxidants for biodiesel. Industrial Crops and Products, Amsterdam, v. 128, p. 331-337, 2019. 
VARATHARAJAN, K.; PUSHPARANI, D. S. Screening of antioxidant additives for biodiesel fuels. Renewable and

Sustainable Energy Reviews, London, v. 82, p. 2017-2028, 2018.

XUE, Y.; ZHAO, Z.; XU, G.; LIAN, X.; YANG, C.; ZHAO, W.; MA, P.; LIN, H.; HAN, S. Effect of polyalpha-olefin pour point depressant on cold flow properties of waste cooking oil biodiesel blends. Fuel, London, v. 184, p. 110-117, 2016.
YUAN, M. H.; CHEN, Y. H.; CHEN, J. H.; LUO, Y. M. Dependence of cold filter plugging point on saturated fatty acid profile of biodiesel blends derived from different feedstocks. Fuel, London, v. 195, p. 59-68, 2017. 